\title{
PENETRASI ISLAM DALAM PENDIDIKAN KEAGAMAAN MASYARAKAT MELAYU DI ROKAN HULU
}

\author{
Ellya Roza \\ Universitas Islam Negeri Sultan Syarif Kasim Riau, Indonesia \\ Email: ellya_roza@yahoo.co.id

\section{Yasnel} \\ Universitas Islam Negeri Sultan Syarif Kasim Riau, Indonesia \\ Email: yasnel@uin-suska.ac.id
}

\begin{abstract}
This paper is part of the results of research, one of the objectives is to know the penetration of Islam on religious social, especially the field of education that occurred in the community Rokan Hulu. Due to this study of social science research, the method used is in accordance with the social science method guided by theoretical framework by using qualitative approach done in four stages of work namely (1) heuristics, (2) criticism, (3) interpretation, and (4) historiography. The research is descriptive form of research that gives a description or describes a complex reality so that the explanation and analysis and interpretations are met. The research location is Rokan Hulu Regency because predicted Riau Islamization comes from Barus adjacent to Rokan Hulu. The results prove that Barus became an important port after Melaka in the world of commerce. In addition to trade, they are traders also broadcast the religion of Islam and make emotional connection with the local community and marriage so that many tombs of Middle Eastern communities in Barus that can be witnessed today and has been studied also by scientists from various countries. The spread of Islam in Barus spread to the surrounding area like South Tapanuli known as "Serambi Mekah" of North Sumatra. By looking at the position of Rokan Hulu adjacent to South Tapanuli, it can be predicted that will be affected by the Islamization so that it will affect the religious social community of Rokan Hulu including education. The nickname of "Negeri Seribu Suluk" to Rokan Hulu is an indication that Rokan Hulu is a temple of Barus Islamization so that it affects the religious education that grows and develops in Rokan Hulu Malay society such as the number of houses of worship and "surau-surau suluk" which until now still become the icon of the area. The birth of the Sufis who developed the Naqsyabandiyah congregation in Rokan Hulu was an implementation of the religious life of the Malay Rokan Hulu people, in which they chose a special way of nicknaming to draw closer to Allah SWT.
\end{abstract}

Keywords: penetration of Islam, religious education, tarekat, suluk 


\section{A. Pendahuluan}

Dikarenakan salah satu sasaran pembangunan nasional adalah penggalian sejarah daerah dalam rangka memperkaya sejarah nasional, maka penggaliaan sejarah penetrasi Islam dan pengaruhnya terhadap sosial keagamaan terutama aspek pendidikan masyarakat tempatan dapat dijadikan sebagai salah satu sumber maupun bagian terpenting dari sejarah nasional, karena sejarah nasional merupakan sejarah bangsa Indonesia. Artinya menggali peristiwa di sebuah daerah, maka akan terlihat sebuah proses yang telah mengubah tatanan kehidupan dan keyakinan masyarakat secara umumnya sehingga wujud karakter bangsa yang lebih terarah. Sebagaimana yang dikatakan oleh Heri Gunawan bahwa karakter diyakini sebagai aspek penting dalam peningkatan sumber daya manusia karena turut menentukan kemajuan suatu bangsa. ${ }^{1}$ Dengan kata lain bahwa sumber daya manusia sangat berperan dalam perkembangan ilmu pengetahuan dan kemajuan peradaban bangsa. Sebagaimana pandangan Nurcholis Madjid, bahwa kemajuan suatu bangsa lebih ditentukan oleh sumber daya manusianya daripada sumber daya alamnya. Pendapat ini didasarkan kepada sumber daya alam Indonesia yang termasuk nomor tiga di dunia, namun bukan berarti bangsa Indonesia adalah negara nomor tiga makmur di dunia, karena di sana sini memang masih banyak sekali masyarakat yang hidup di bawah standar. Artinya sumber daya manusianya belum mampu mengatasi permasalahan tersebut. Jika bicara tentang sumber daya manusia, bukan berarti keahlian saja yang harus diperhatikan, namun di sisi lain juga harus memperhatikan sikap yang mendorong dan menopang daya cipta serta kreatifitas yang memang merupakan bingkai budaya sehingga nampak nyata dalam pribadi-pribadi masyarakatnya. Di samping itu sikap dan kreatifitas ini adalah usaha dalam pengenalan dan pemahaman terhadap nilai-nilai yang pernah hidup dalam masyarakat dan sekaligus modal dalam pembangunan di masa kini dan akan datang. ${ }^{2}$

Terjadinya penetrasi Islam di wilayah Nusantara tidaklah bersamaan karena kerajaan-kerajaan dan daerah-daerah yang didatangi Islam mempunyai situasi politik dan kepercayaan yang berlainan. Selain membawa pembaharuan di bidang keyakinan, Islam juga membawa pengaruh terhadap perkembangan pendidikan keagamaan

${ }^{1}$ Heri Gunawan, Pendidikan Karakter Konsep dan Implementasi, (Bandung: Alfabeta, 2012), h.

${ }^{2}$ Nurcholis Madjid, Tradisi Islam, Peran dan Fungsinya dalam Pembangunan di Indonesia, (Jakarta: Paramadina, 1997), h.187. 
masyarakat. Riau termasuk salah-satu daerah yang terletak di pesisir pantai timur Sumatera Tengah yang notabenenya adalah tempat persinggahan pedagang bangsa asing terutama bangsa Arab, maka dengan sendirinya akan mengalami hal yang sama dengan daerah lain yang didatangi oleh bangsa Arab. Artinya Riau merupakan daerah yang berhubungan langsung dengan Selat Melaka yang merupakan jalur lalulintas perdagangan. Hal ini sangat bersesuaian dengan hasil penelitian Azyumardi Azra yang mengatakan bahwa telah terjadi hubungan antara penduduk Nusantara dengan bangsa Arab jauh sebelum kelahiran Islam yang diperkirakan pada abad ketiga sebelum Masehi. ${ }^{3}$ Bahkan dikatakan lebih lanjut bahwa kontak paling awal antara kedua wilayah tersebut terutama yang berkaitan dengan perdagangan telah bermula sejak masa Phunisia dan Saba, di mana kapal-kapal Arab dan Persia yang berdagang ke Cina melakukan pengembaraan pula di Nusantara. Hal ini terjadi karena pada waktu itu Kepulauan Melayu telah menjadi tempat persinggahan para pedagang yang berlayar ke Cina dan mereka telah menjalin hubungan dengan masyarakat sekitar terutama daerah pesisir. ${ }^{4}$ Demikian juga Budi Sulistiono telah memprediksi bahwa hubungan kegiatan perdagangan di Benua Asia, khususnya hubungan antara Arab, Persia, Cina dan India telah tumbuh sejak awal tarikh Masehi. ${ }^{5}$ Oleh karena itu, ketika terjadi proses penetrasi Islam di Nusantara, maka Riau dengan sendirinya juga kena imbasnya karena wilayah Riau berada di dekat kota perdagangan yang didatangi oleh pedagang asing terutama pedagang Arab.

Selain Selat Melaka di pantai timur Sumatera terdapat pula sebuah pelabuhan di pantai barat Sumatera yang bernama Barus. Barus merupakan daerah penghasil kamper bermutu tinggi yang sangat terkenal di berbagai bangsa di dunia. Di Timur Tengah, kamper digunakan untuk bahan pengawetan mayat pada masa itu sehingga keharuman Barus dengan kampernya telah merambah sampai ke Arab dan Persia sana. Oleh karena itu, para pedagang Arab telah sampai ke Barus bersamaan dengan kedatangan mereka ke Aceh yakni Perlak dan Samudera Pasai. Selain berdagang mereka juga menyebarkan dakwah Islamiyah dan ini tentu saja akan berdampak terhadap Rokan Hulu yang posisinya terletak berdekatan dengan Barus. Dari Barus yang termasuk ke dalam

${ }^{3}$ Azyumardi Azra, Jaringan Ulama Timur Tengah dan Kepulauan Nusantara Abad XVII-XVIII: Melacak Akar-akar Pembaharuan Pemikiran Islam di Indonesia, (Bandung: Mizan, 1994), h.11.

${ }^{4}$ Ibid.

${ }^{5}$ Budi Sulistiono, "Islam dan Tamadun Melayu: Menatap Masa Depan," Jurnal Sosial Budaya, Vol. IX. No.1, (104-114), ISSN.1979-2603, (Pekanbaru: LPPM UIN Suska Riau, 2014), h.104. 
wilayah Tapanuli Tengah, penyebaran Islam dilanjutkan ke Tapanuli Selatan, yang dikenal sebagai Serambi Mekahnya Sumatera Utara, di mana penduduk kabupaten ini 95\% adalah muslim sehingga dikenal dengan Melayunya Sumatera Utara. Pohon Barus yang diminati oleh pedagang Timur Tengah banyak terdapat di hutan Tapanuli yang dulunya masuk wilayah Barus. Dari Barus dakwah Islamiyah diprediksi meluas ke wilayah Riau, tepatnya Rokan Hulu sekarang yakni daerah yang terletak di perbatasan antara Provinsi Riau dan Sumatera Utara. Rokan Hulu dikenal sebagai 'Kota Seribu Suluk,' yang dulunya masuk wilayah Kabupaten Kampar yang dijuluki dengan Serambi Mekahnya Riau karena kehidupannya yang agamis dan panatisme keislamannya sangat tinggi. Sebutan Kota Seribu Suluk kepada Rokan Hulu merupakan indikasi bahwa religiulitas kehidupan masyarakatnya tinggi.

Merujuk kepada perjalanan sejarah sebagaimana yang dipaparkan di atas, penetrasi Islam di Rokan Hulu sangat mungkin terjadi karena berada di bagian utara Riau yang bersebelahan dengan Barus. Oleh karena itu sangat menarik untuk diteliti karena dapat memunculkan teori Islamisasi di wilayah Riau. Oleh karena itu sangat tepat kiranya apabila penetrasi Islam di Rokan Hulu dapat ditelusuri dan dibuktikan melalui penelitian ini dimana nantinya terlihat pengaruh yang ditimbulkan akibat adanya penetrasi Islam tersebut terhadap sosial keagamaan masyarakat sehingga akan menambah khazanah keilmuan terutama bidang studi Sejarah Kebudayaan Islam di Propinsi Riau. Selanjutnya, penelitian ini sangat bermanfaat dan berguna bagi berbagai pihak di antaranya bagi pemerintah sebagai implementasi visi dan misi Riau tahun 2020. Kemudian juga bagi kalangan akademisi dan institusi yang berguna untuk pengembangan ilmu pengetahuan secara integritas dan yang tidak kalah pentingnya adalah sangat bermanfaat bagi masyarakat, agar dapat lebih mengenal sejarah bangsa yang berhubungan dengan dampak positif penetrasi Islam terhadap pendidikan keagamaan masyarakat.

Penelitian ini dalam pelaksanaannya memerlukan metode. Metode mengandung makna cara melakukan sesuatu. ${ }^{6}$ Sedangkan penelitian ini merupakan penelitian ilmuilmu sosial, maka metode yang digunakan sesuai dengan metode ilmu sosial yang dituntun oleh kerangka pemikiran teoritis. Metode ilmu sosial adalah seperangkat prinsip dan aturan yang sistematis yang disusun untuk membantu dalam pengumpulan 1030.

${ }^{6}$ Tim Penyusun, Kamus Besar Bahasa Indonesia, (Jakarta: Pusat Bahasa Indonesia, 2008), h. 
sumber-sumber secara efektif, menilainya secara kritis dan menyajikan suatu sintesis hasil yang dicapai. ${ }^{7}$ Penelitian ilmu sosial dilakukan dengan empat tahapan kerja yaitu : (1) heuristik, (2) kritik, (3) interpretasi, dan (4) historiografi. ${ }^{8}$ Kemudian dalam penelitian ini digunakan dua pendekatan yakni pendekatan kualitatif dan pendekatan kuantitatif. ${ }^{9}$ Gabungan ini dilakukan dengan harapan dapat memperkaya data dan lebih memahami permasalahan yang diteliti. Sedangkan bentuk penelitian ini adalah deskriptif yaitu penelitian yang memberi sesuatu uraian dan gambaran secara rinci atau menggambarkan realitas yang kompleks sehingga penjelasan dan analitikal interpretatifnya tercapai. ${ }^{10}$ Lokasi penelitian adalah Kabupaten Rokan Hulu Lokasi ini diprediksi karena penetrasi Islam bermula dari Barus yang menjadi bagian dari Tapanuli Selatan. Oleh karena itu dalam rangka mencari data, maka observasi penuh dilakukan di Rokan Hulu dengan cara wawancara kepada tokoh-tokoh masyarakat yang bermukim di sana dan menelusuri jejak perjalanan Islamisasi yang disebarkan oleh para tokoh penyebar ketika itu.

\section{B. Barus sebagai Pelabuhan Dagang Nusantara}

Meskipun Islam telah masuk pada abad ke-7 atau ke-8 Masehi di Indonesia, namun penganut agama ini masih terbatas di lingkungan para pedagang dan penduduk kota di pesisir pantai. Hal ini disebabkan masih kuatnya pengaruh Hindu Budha yang merupakan agama negara dalam Kerajaan Sriwijaya waktu itu yang menyebabkan Islamisasi tidak berkembang, dan kondisi seperti ini berlangsung sampai abad ke-12 M. ${ }^{11}$ Artinya, penetrasi Islam Rokan Hulu tidak terlepas dari sejarah masa lampau masyarakat yang hidup di segala penjuru dunia karena para pedagang datang dengan tujuan yang sama. Rokan Hulu pada masa lalu merupakan salah satu daerah yang

\footnotetext{
${ }^{7}$ Mohd. Nazir, Metode Penelitian, (Jakarta: Bina Aksara, 2000), h. 63. Baca juga Hartono, Metodologi Penelitian, (Pekanbaru: Zanafa Publising, 2011); Garraghan, A Guide to Historical Method, Vol. 1, (New York: Fordham University Press, 1957); Nina Herlina, Metode Sejarah, (Bandung: Satra Historika, 2008); J. Vredenbergt, Metode dan Teknik Penelitian, (Jakarta: Gramedia, 2002).

${ }^{8}$ Suwardi Endaswara, Metode, Teori, Teknik Penelitian Kebudayaan, (Yogyakarta: Pustaka Widyataman, 2006). Baca juga Stuart, History as Art and as Science: Twin Visitas on the Past, (New York: Harper Torchbooks, 1964); Garraghan, A Guide to Historical Method, Vol. 1, (New York: Fordham University Press, 1957).

${ }^{9}$ Sugiyono, Metode Penelitian Kuantitatif Kualitatif dan R\&D, (Bandung: Alfabeta, 2013). Baca pula Muhadjir, Metodoogi Penelitian Kualitatif, (Yogyakarta: Rake Sarasian, 2000); Lexy J. Moloeng, Metode Penelitian Kualitatif, (Bandung: Rosdakarya, 1997).

${ }^{10}$ Mohd. Nazir, op.cit., h. 63.

${ }^{11}$ H. Mahidin Said, Adat dan Kebudayaan Pasir Pengaraian Riau, (Pekanbaru: Badan Pembinaan Kesenian Daerah Riau, 2003), h. 78.
} 
menghasilkan rempah-rempah yang selalu menjadi tujuan utama pedagang yang datang, baik dari Timur Tengah maupun dari Eropa. ${ }^{12}$ Oleh karena itu, dikatakan oleh Hamka bahwa Islam sudah sampai di pantai barat Sumatera pada abad ke 7 Masehi yang dibawa oleh pedagang Arab. ${ }^{13}$ Lebih lanjut dikatakan bahwa sekitar tahun 632 Masehi satu ekspedisi yang terdiri dari beberapa orang saudagar Arab dan beberapa orang mubaligh Islam berlayar ke negeri Cina dan tinggal di Canton namun sebelum sampai di Canton, terlebih dahulu mereka sampai di pelabuhan Barus. ${ }^{14}$ Menurut Abdullah Abbas Nasution bahwa rombongan saudagar dan mubaligh Arab tersebut dipimpin oleh Wahab ibn Abu Kabsah yang merupakan utusan khusus Nabi Muhammad SAW ke negeri China Selatan yang bertujuan untuk menemui Sri Maharaja Dinasti Tang guna menyampaikan surat dakwah Nabi Muhammad SAW kepada Sri Maharaja Tai-Ta-Song di China Selatan. ${ }^{15}$ Lebih lanjut dikatakan pula bahwa pada tahun 717 M. (82 H.) berlayar 33 buah kapal Arab-Persia yang diketuai oleh Zahid ke Tiongkok dan sebelum sampai di Tiongkok mereka singgah terlebih dahulu di Aceh, Kedah, Siam, Brunei dan lain-lain. Kepentingan mereka adalah untuk berdagang dan menyebarkan Islam. ${ }^{16}$ Pendapat yang dikemukakan tersebut sampai saat ini belum ada yang membantahnya bahkan pendapat ini telah didukung oleh Syed Naquib al-Attas dengan mengkaji literatur Melayu abad ke-10 dan 11 H. (16-17 M.) karena dalam berbagai tulisan Melayu selalu disebutkan peran bangsa Arab dalam proses Islamisasi. ${ }^{17}$ Bahkan Mahyudin H. Yahya mengemukakan bahwa perkampungan Islam di Sumatera Utara yang bernama "Ta-shih" telah ditemukan pada tahun 650 M. (30 H.). Perkampungan tersebut dihuni oleh orang-orang Arab yang datang ke Sumatera pada abad ke-7 Masehi. ${ }^{18}$ Selanjutnya Ta-shih telah pula membuat perhubungan diplomatik dengan Kerajaan China sampai tahun 655 M. ${ }^{19}$

\footnotetext{
${ }^{12}$ Ibid.

${ }^{13}$ Pendapat Hamka dapat dibaca secara lengkap dalam Hasymi, Sejarah Masuk dan Berkembangnya Islam di Indonesia, Cet. ke-3, (Banda Aceh: Almaarif, 1993), h. 7

${ }^{14}$ Ibid.

${ }^{15}$ Abdullah Abbas Nasution, Syarahan, makalah yang disampaikan di UKM Malaysia pada tanggal 21-24 Februauri 1978 dan tidak diterbitkan, Kedah: Pustaka Nasution.

${ }^{16}$ Ibid.

${ }^{17}$ Syed Naquib Al-Attas, Islam dalam Sejarah dan Kebudayaan Melayu, (Kuala Lumpur: Universiti Kebangsaan Malaysia, 1972), h. 23.

${ }^{18}$ Mahyudin H. Yahya, Sejarah Islam, (Kuala Lumpur: Fajar Bakti, 1993), h. 11 h. 174 .

${ }^{19}$ Azmi, "Islam di Aceh, Masuk dan Berkembangnya hingga Abad XVI," dalam Hasymi, op.cit.,
} 
Syarif Alwi bin Thohir Al-Haddad salah seorang Mufti Kesultanan Johor Malaysia mengatakan bahwa sesungguhnya Islam telah mempunyai raja-raja di Sumatera pada abad ketujuh. ${ }^{20}$ Kemudian dalam Hikayat Raja-raja Pasai dicatatkan bahwa ada seorang dari Mekkah bernama Syeikh Ismail yang datang ke Pasai dengan sebuah kapal. Ketika sampai di Pasai syeikh tersebut mengislamkan rajanya yang bernama Merah Silu dengan memakai gelar Malik al-Saleh. ${ }^{21}$ Menurut Mahdini ada seorang yang bernama Syeikh Abdullah al-Yamani datang dari Mekkah ke Nusantara lalu mengislamkan Merong Mahawangsa dan sebagian menterinya serta penduduk dan setelah memeluk Islam Mahawangsa memakai gelar Sultan Muzaffar Syah. ${ }^{22}$

Islamisasi di Indonesia berlangsung damai karena misi dakwah Islamiyah dibingkai dengan perilaku yang Islami oleh para pedagang Arab di Indonesia menjadikan bahan pertimbangan dan salah satu daya tarik rakyat tempat persinggahan untuk lebih jauh mengenal misi agama yang dibawa para pedagang Arab tersebut. Kejujuran mereka dalam berdagang menjadi sebuah alasan logis untuk mendapatkan simpati rakyat. Dari Aceh menuju Sumatera Utara, tentu menjadi arah pengembangan misi dakwah Islam yang dijalankan secara estafet. Artinya urgensi dakwah dalam penetrasi Islam tidak lepas dari kreativitas muballigh dan tokoh-tokoh Islam yang turut mengambil peran penting. Mereka ini tersebar di seluruh pelosok Indonesia. Boleh jadi, ketika orang Arab sampai di Samudera Pasai (Aceh) lalu beranjak menyeberang lewat Lautan Hindia, sampailah ke pesisir pantai Barus, sehingga wajar kalau di kota ini banyak ditemukan situs makam komunitas Arab.

Barus yang menjadi bagian wilayah Tapanuli Tengah kemudian melanjutkan penyebaran Islam Tapanuli Selatan yang dikenal sebagai Serambi Mekahnya Sumatera Utara, di mana penduduk kabupaten ini 95\% adalah muslim. Tidak heran kalau pesantren, pondok-pondok hafidz, majlis-majlis pengajian tumbuh subur di sini. Kabupaten ini biasanya disebut sebagai penghuni suku batak Mandailing yang bahasanya lembut seperti bahasa Melayu, maka tidak jarang banyak sinyalemen orang mengatakan bahwa masyarakat di sini identik dengan Melayunya Sumatera Utara.

\footnotetext{
${ }^{20}$ Syarif Alwi bin Thohir Al-Haddad, Al-Madkhal ila Tarikh al-Islami fi al-Syarq al-Aqsha, Jeddah: Alam al-Ma'rifah,1985), h. 124.

${ }^{21}$ A.H. Hill (pnyl), "Hikayat Raja-raja Pasai," JMBRAS. No. 33, 1960, h. 58-60. Baca juga Siti Hawa Saleh, Hikayat Merong Mahawangsa, (Kuala Lumpur: University Malaya Press, 1970).

${ }^{22}$ Mahdini, Islam dan Kebudayaan Melayu, (Pekanbaru: Daulat Riau, 2003), h. 15. Baca juga Djajadiningrat, Kesultanan Aceh, (Banda Aceh: Departeman P\&K, 1982).
} 
Karena pada hakikatnya suku Melayu itu identik dengan Islam, maka setiap orang Islam adalah Melayu dan yang bukan orang Islam, sudah pasti bukan Melayu. Dengan melihat posisi Riau dengan Barus, maka proses Islamisasi di Riau melalui jalur utara sangat mungkin terjadi karena jalur perjalanan para pedagang yang menggunakan transportasi air merupakan transport utama yang menyusuri hulu Sungai Rokan sampai ke daerah Tapanuli Selatan.

Selain itu pohon kamper yakni bahan untuk kapur barus yang banyak tumbuh di Barus merupakan bahan utama dalam pengobatan di daerah Arab dan Persia. Kehebatan kapur ini pun menjalar ke seluruh dunia dan mengakibatkan dia diburu dan harganya semakin tinggi. Sedangkan rempah-rempah yang banyak tumbuh subur di Riau mengakibatkan Riau juga didatangi oleh para pedagang Arab dan Persia tersebut. Setelah mereka berada di Barus mereka melanjutkan perjalanan menuju Riau guna membeli rempah-rempah. Oleh karena itu sangat besar kemungkinan Rokan Hulu merupakan daerah awal terjadinya penetrasi Islam di Riau mengingat daerah Rokan Hulu terletak di bagian utara yang tentunya akan terjadi hubungan para pedagang dengan masyarakatnya. Selain itu julukan Negeri Seribu Suluk terhadap Rokan Hulu merupakan implementasi dari penyebaran Islam di Barus ke Rokan Hulu. Dengan kata lain, Rokan Hulu terimbas oleh Islam di Barus bahkan dapat dikatakan menjadi tempiasan Islamisasi dari Barus. Sebagaimana yang dikatakan oleh Hamka bahwa kerajaan yang menyebarkan Islam ke Minangkabau di antaranya adalah dari Kerajaan Kunto Darussalam, Rokan. ${ }^{23}$ Dalam Sejarah Minangkabau dikatakan bahwa Islam menyebar di Minangkabau terjadi antara tahun 1285-1522. ${ }^{24}$

Sebagaimana yang telah dijelaskan sebelum ini bahwa Islam sudah sampai di pantai barat Sumatera pada abad ke-7 Masehi yang dibawa oleh pedagang Arab. Kedatangan pedagang Arab tersebut tentu saja melalui pelabuhan dagang yang dikenal dalam berbagai literatur bernama Barus. Nurfaisal mengatakan bahwa tujuan utama pedagang Arab bukanlah untuk menyebarkan agama Islam karena jauh sebelum itu mereka sudah sampai di Barus untuk berdagang. Di antara komoditas dagang yang mereka cari adalah kamper (yang disebut dengan kapur barus), kemenyan dan emas. Artinya Barus dan kapur barus secara tidak langsung telah mengundang masuknya

\footnotetext{
${ }^{23}$ Hamka, Antara Fakta dan Kenyataan Tuanku Rao, (Jakarta: Bulan Bintang, 1974), h.152. Baca juga Hamka, Sejarah Umat Islam, Jilid II, (Jakarta: Bulan Bintang, 1980).

${ }^{24}$ M.D. Mansoer, et.al., Sejarah Minangkabau, (Jakarta: Bharata, 1970), h. 149.
} 
agama Islam ke Nusantara pada masa awal Islam melalui para pedagang Arab yang telah memeluk Islam. ${ }^{25}$

Barus dikenal juga dengan nama lain yaitu Fansur dan biasanya dihubungkan dengan kapus barus yang sangat diperlukan oleh negeri Mesir khususnya digunakan untuk memelihara mayat-mayat dari busuk dan rusak. Kapur barus merupakan barang dagang yang penting dan berharga jual tinggi. Oleh sebab itu pelabuhan Barus adalah salah satu pelabuhan yang mesti dikunjungi oleh kapal-kapal dagang Arab. Sesuai dengan pendapat Azra bahwa jika dilihat secara nyata jauh ke belakang sebenarnya telah terjadi hubungan antara penduduk Indonesia yang dulunya disebut Nusantara dengan bangsa Arab sebelum kelahiran Islam. ${ }^{26}$

Situs "Banda Bapahek" di Saruaso Batusangkar, Sumatera Barat tertulis pada dinding batu itu dalam dua bahasa yang berisikan maklumat Adityawarman kepada rakyatnya. Di sebelah kiri terdiri daripada 10 baris yang dipahat dalam bahasa Sanskerta, sedangkan di sebelah kanan terdiri daripada 13 baris yang diyakini dalam bahasa Tamil, India Selatan. Mereka diperkirakan masuk ke Sumatera Tengah (Minangkabau) melalui suatu pelabuhan yang dulunya merupakan salah satu kota dagang tertua, terbesar dan paling internasional dibanding kota pelabuhan manapun di Nusantara ini yaitu Barus. ${ }^{27}$ Kemudian disebutkan juga bahwa banyak bukti yang lain terdapat di Barus dalam bentuk batu-batu bertulis dan beberapa kosa kata yang berasal dari bahasa Tamil seperti mahligai. Oleh karena itu, sangat kuat dugaan bahwa penduduk kota Barus pada umumnya adalah pedagang yang berasal dari India Selatan yaitu Tamil. Mereka inilah memonopoli perdagangan kapur barus ke berbagai negara waktu itu. $^{28}$

Kemasyhuran Barus, Fansur dan kapur barus sudah ditemui sejak awal Masehi bahkan kemenyan dari Barus dikatakan sudah dipakai untuk mengawetkan raja-raja Mesir. Ia disebut-sebut dalam berbagai bahasa di dunia termasuk di dalam kitab suci alQur'an dan Injil. Bahkan Barus juga disebut sebagai Kerajaan Barus Raya atau jaringan

\footnotetext{
${ }^{25}$ Nurfaisal, Kesaksian Barus dan Kapur Barus dalam Sejarah Awal Islam Nusantara, Laporan Hasil Penelitian yang tidak diterbitkan, (Pekanbaru: LP2M UIN Suska Riau), 2013, h.22.

${ }^{26}$ Azyumardi Azra, 1994, op.cit., h. 11.

${ }^{27}$ Rusli Amran, Sumatera Barat Hingga Plakat Panjang, (Jakarta: Sinar Harapan, 1981), h. 4445.

${ }^{28}$ Ibid.
} 
perdagangan sekelas dengan Kerajaan Sriwijaya. ${ }^{29}$ Barus memiliki situs sejarah yang menarik untuk diteliti sehingga para peneliti baik dari dalam negeri maupun luar negeri datang ke Barus guna melakukan penelitian. Misalnya Pusat Penelitian Arkeologi melakukan penelitian terhadap situs bersejarah di Barus. Kemudian peneliti Perancis melakukan penelitian pula pada situs pemukiman kuno Lobu Tua. ${ }^{30}$

Di Barus banyak terdapat lokasi pemakaman kuno dan yang tertinggi adalah Komplek Makam Papan Tinggi yang terletak di atas bukit setinggi 270 meter dari permukaan laut dengan lebih 700 anak tangga. Sedangkan yang terbesar adalah Komplek Pemakaman Mahligai. Makam-makam tua di Barus ini oleh masyarakat dikenal dengan sebutan "Kuburan Aulia 44."31 Di antara makam-makam tua tersebut juga ada situs pemakaman orang-orang Arab Muslim yang datang bersamaan dengan masuknya Islam ke Indonesia tepatnya di Barus pada abad ke-7 Masehi yakni pada masa Rasulullah masih berada di Mekkah. Komplek pemakaman tersebut diprediksi sebagai pemakaman muslim karena pada masing-masing makam dipenuhi oleh batu nisan di antaranya bertuliskan kalimah tauhid La Ilaha illa Allah Muhammad Rasulullah. $^{32}$

Dalam historiografi Indonesia, Barus dikenal dalam dua hal, pertama sebagai tempat kediaman penyair mistik Melayu Hamzah Fansuri, kedua sebagai sumber kapur barus dan kemenyan, di mana kedua jenis tersebut termasuk barang dagangan Sumatera dan Cina semenjak awal abad ke-7 Masehi dan pada waktu-waktu tertentu juga dicari oleh pedagang dari India dan Timur Tengah. ${ }^{33}$ Oleh karena itu, Barus dijuluki 'Kota Tua,' karena Barus dulunya merupakan pelabuhan internasional yang disinggahi berbagai suku bangsa dan pedagang di dunia untuk mendapatkan kapur barus dan rempah-rempah lainnya. Dengan demikian, sangat besar kemungkinan Islamisasi Riau berasal dari utara mengingat adanya hubungan kekerabatan masyarakat yang diaplikasikan pada kerajaan yang ada di utara Riau yakni Kerajaan Rokan.

\footnotetext{
${ }^{29}$ Nurfaisal, op.cit., h.23

${ }^{30}$ Claude Gulliot, Lobu Tua: Sejarah Awal Barus, Terj. Daniel Perret, (Jakarta: Ecole Francaise d'extreme-orient Association Archipel, Pusat Penelitian Arkeologi, Yayasan Obor Indonesia, 2002), h. 6. ${ }^{31}$ Ibid.

${ }^{32}$ Ladvik Kalus, "Sumber-sumber Epigraf Islam di Barus" dalam Claude Gulliot, Barus Seribu Tahun Yang Lalu, Terj. Daniel Perret \& Atika Sari Fanani, (Jakarta, Paris: Pusat Penelitian dan Pengembangan Arkeologi Nasional, 2008), h. 298.

${ }^{33}$ Jane Drakard (ed.), Sejarah Raja-raja Barus, (Jakarta dan Bandung: Usaha Bersama Penerbit Angkasa dan Ecole Francaise D’ektreme-Orient, 1988), h. 31.
} 


\section{Kerajaan Rokan}

Pusat pemerintahan Kerajaan Rokan pada mulanya di Kota Intan yaitu suatu tempat dekat Kota Lama. Dalam perjalanan sejarah kerajaan tersebut, pusat pemerintahannya selalu berpindah-pindah dan praktis nama kerajaan itu sewaktu-waktu juga ikut berubah. Mula-mula pusat pemerintahan Kerajaan Rokan di Kota Lama kemudian pindah ke Pekaitan dan akhirnya pindah lagi ke Rantau Kasai. ${ }^{34}$ Artinya banyak nama yang diberikan kepada kerajaan itu. Hal itu menimbulkan kesan bahwa nama resminya tidak tercatat dalam sumber karena kebiasaan masyarakat yang hidup pada zaman lampau selalu memberi nama sebuah kerajaan berdasarkan keadaan tempat dan apa yang banyak tumbuh di daerah itu. Misalnya ada yang menyebut dengan Kerajaan Kunto Darussalam, ada yang menamakan Kerajaan Rokan dan ada pula yang menyebutnya dengan Kerajaan Kota Lama Kunto. Sebagaimana pendapat Hamka bahwa kerajaan yang menyebarkan Islam ke Minangkabau di antaranya adalah dari Kerajaan Kunto Darussalam. ${ }^{35}$ Sedangkan Kunto Darussalam itu sendiri berada di wilayah Kerajaan Rokan. Selanjutnya dalam Sejarah Minangkabau dikatakan bahwa Islam menyebar di Minangkabau terjadi antara tahun 1285-1522 M. ${ }^{36}$ Berdasarkan pendapat Hamka, maka diperkirakan penyebaran itu terjadi antara abad ke-13 sampai 16 Masehi. Perlu dipahami bahwa nama Kunto Darussalam yang dimaksudkan oleh Hamka hanya ada di Rokan sedangkan Kerajaan Kuntu ada di Kampar Kiri.

Apabila dicermati mengenai makna kata Rokan, maka dapat dikatakan bahwa kata Rokan berasal dari bahasa Arab "rakana" yang mengandung arti damai atau rukun. ${ }^{37}$ Diprediksi demikian karena nama ini merupakan refleksi dari keadaan rakyat atau masyarakat yang selalu rukun dan mementingkan kedamaian, baik dengan sesama penduduk negeri, maupun dengan orang luar negeri sehingga nama tersebut diabadikan menjadi nama negeri. Dari nama tersebut menunjukkan adanya pengaruh Arab, baik pedagang maupun penyebar Islam.

Rokan sebagai nama sebuah negeri, kerajaan, wilayah dan lain-lainnya ternyata telah tercantum dalam naskah Nagara Kretagama karya Empu Prapanca yang selesai ditulis pada tahun 1365 M. Nagara Kretagama adalah naskah yang mengandung cerita

\footnotetext{
${ }^{34}$ H. Wan Tamim, Lintasan Sejarah Rokan, (Pekanbaru: BPKD Prop. Riau, 1972), h. 17.

${ }^{35}$ Hamka, Antara Fakta..., op.cit., h.152.

${ }^{36}$ M.D. Mansoer, op. cit., h.149.

${ }^{37}$ A.W. Munawwir, Kamus Arab Al-Munawwir Arab-Indonesia, Edisi Lux, (Yogyakarta: Pustaka Progresif, 1984), h. 699.
} 
sejarah tentang Kerajaan Majapahit di masa yang lampau. Di dalam naskah tersebut pada pupuh atau episode 13 disebutkan bahwa negara bawahan Majapahit atau negaranegara yang telah tunduk kepada Majapahit adalah Melayu yaitu Jambi, Palembang, Toba, Darmasraya, Kandis, Kahwas, Minangkabau, Siak, Rokan, Kampar dan Pane. Juga Lawas dengan samudera serta Lamuri, Batam, Lampung, dan Barus. Juga Negaranegara di pulau Tanjungnegara, Kapuas, Katingan, Sampit, Kota Lingga, Kota Waringin, Sambas, dan Lawai. ${ }^{38}$

Rokan termasuk kerajaan yang cepat berkembang karena hasil rempah-rempah yang dimilikinya dan juga relasi perdagangannya dengan negeri lain seperti Malaka. Bandar Rokan, Kampar, Inderagiri dan Siak merupakan lokasi-lokasi penting bagi Malaka untuk menguasai jalur distribusi komoditas seperti emas, lada, gaharu, dan sebagainya dari Tanah Datar di Sumatera Barat menuju ke Selat Melaka. Untuk mempererat ikatan tersebut Raja Malaka, Sultan Mahmud Syah I menjalin hubungan kekerabatan dengan Rokan yakni dengan memperistri putri Raja Rokan dan menjadikannya sebagai permaisuri. Dengan demikian, hubungan antara Malaka dan Rokan jadi semakin erat. Dari perkawinan Mahmud Syah I dengan putri Raja Rokan, maka lahir seorang anak yang bernama Ibrahim. Setelah Mahmud Syah I wafat, Ibrahim sempat menjadi raja di Malaka. Namun, Raja Ibrahim kemudian dibunuh oleh Raja Kasim Muhammad Syah, saudara seayah dari ibu asli Malaka.

Sejak Malaka dikalahkan Portugis, Kerajaan Rokan mengalami kemunduran, karena terus mendapatkan ancaman dari Aru dan Aceh dari bagian utara sehingga Kerajaan Rokan akhirnya mengalami kehancuran. Aktivitas perdagangan kembali muncul setelah berdirinya beberapa kerajaan di sepanjang aliran Sungai Rokan yaitu Kerajaan Pekaitan dan Batu Hampar. Setelah Kerajaan Pekaitan dan Batu Hampar lenyap, kemudian muncul tiga kerajaan lagi di bagian hilir Sungai Rokan yaitu (1) Kerajaan Kubu dengan ibunegeri Teluk Merbabu; (2) Kerajaan Bangko dengan ibunegeri Bantaian; dan (3) Kerajaan Tanah Putih dengan ibunegeri Tanah Putih. Sementara di bagian hulu, muncul lima kerajaan yang diperintah secara turun-temurun oleh bangsawan raja yakni (1) Kerajaan Tambusai, ibunegerinya Dalu-dalu; (2) Kerajaan Rambah, ibunegerinya Pasir Pengaraian; (3) Kerajaan Kepenuhan,

${ }^{38}$ Slamet Mulyana, Tafsir Sejarah Nagara Kretagama karya Empu Prapanca, (Jakarta: LKIS, 2006), h. 345. 
ibunegerinya Koto Tengah; (4) Kerajaan Kunto Dar el-Salam, ibunegerinya Kota Lama; (5) Kerajaan Rokan, ibunegerinya Rokan IV Koto.

Kerajaan tersebut berada di bawah pengawasan kekuasaan Belanda pada abad ke-17, setelah terlebih dahulu mengusir Portugis dari Malaka pada tahun 1641 M. Pihak Belanda juga membangun loji-loji di bandar-bandar penting di muara Sungai Rokan, Kampar dan Siak, baik melalui perjanjian maupun dengan kekerasan senjata. Ketika memasuki abad ke-18, Siak di bawah Raja Kecil muncul menjadi kekuatan politik penting di wilayah Riau dan sekitarnya sehingga Kerajaan Tanah Putih, Bangko dan Kubu sejak abad ke-18 M, tunduk di bawah kekuasaan Kerajaan Siak. Untuk memperkuat pengaruh Siak, Sultan Said Ali lalu mempersunting seorang puteri Kerajaan Tanah Putih. ${ }^{39}$ Pada masa Sultan Siak ke-11 yakni Sultan Syarif Hasyim, Kerajaan Tanah Putih dijadikan bagian wilayah dan diperintah oleh seorang Kepala Negeri bergelar Datuk Setia Maharaja dan daerahnya disebut Negeri. Sementara di daerah Rokan Hulu, rajanya bergelar Yang Dipertuan dan daerahnya disebut Luhak. ${ }^{40}$ Setelah itu, aktivitas politik dan perdagangan di sepanjang aliran Sungai Rokan meredup selama beberapa abad.

Melihat kondisi bangunan istana Kerajaan Rokan sekarang ini sangat memprihatinkan, di mana bangunannya sudah tua dan banyak yang lapuk sehingga apabila dinaiki oleh banyak orang, maka dikahawatirkan bangunan istana tidak sanggup untuk menampungnya. Bukannya pemerintah tidak memperhatikan keadaan istana tersebut akan tetapi faktor usia. Demikian kata bapak penjaga istana tersebut. ${ }^{41}$ Apabila diperhatikan dengan seksama, kenyataannya memang demikian sebab bangunan istana yang teridiri dari kayu tentunya akan mengalami pelapukan sehingga sedikit demi sedikit dan secara berangsur-angsur akan mengalami kehancuran jika dibiarkan.

Demikian juga bangunan rumah tradisional yang dibangun di sekitar istana yakni rumah para ketua batin yang berada di bawah Kerajaan Rokan yang berjumlah sepuluh bangunan rumah. Bangunan rumah tersebut juga sudah tidak terplihara lagi bahkan ada yang memanfaatkan dengan yang lain seperti berkedai dan lain sebagainya. ${ }^{42}$ Pada hal pemerintah sudah menjadikan bangunan rumah tersebut untuk percontohan yang akan dilihat oleh pengunjung dari dalam dan luar daerah.

\footnotetext{
${ }^{39}$ Tamim, op.cit., h,17.

${ }^{40}$ Ellya Roza, dkk, Babul Qawaid, Transliterasi dan Analisis, (Pekanbaru: Pemda Siak, 2002), h. 46.

${ }^{41}$ Penjaga Istana Rokan, Wawancara, Sabtu 3 September 2016 di Istana Rokan.

${ }^{42}$ Ibid.
} 


\section{Masuknya Islam di Rokan Hulu}

Mengenai masuknya Islam ke daerah Rokan belum dapat dipastikan, yang dapat diprediksi adalah daerah Rokan pertama kali bersentuhan dengan Islam diperkirakan sekitar abad ke XIV dan ke XV ketika kerajaan-kerajaan Islam sudah mulai muncul dan berdiri. Tidak ada data tentang perkembangan selanjutnya, hingga munculnya Kerajaan Tambusai yang diperintah oleh rajanya yang ke XIV, yakni Sri Sultan Ibrahim pada tahun $1819 \mathrm{M}^{43}$ Pada masa ini agama Islam telah berkembang pesat di sepanjang Sungai Rokan, yang disiarkan oleh muballigh-muballigh Islam yang diperkirakan datang dari Aceh yakni Kerajaan Samudera Pasai yang menjadi negara makmur pada abad ke 14 dan 15 Masehi dan berperan dalam mengislamkan beberapa wilayah di Nusantara termasuk Rokan. Akibat pergolakan kolonial menyebabkan banyak ulama dan keluarga kerajaan hijrah meninggalkan Pasai menuju Rokan. Pada masa inilah kemungkinan negeri-negeri di Riau pada umumnya mulai banyak menganut agama Islam. Tidak mengherankan bila sejak abad ke-15 Masehi, Kerajaan Rokan diperintah seorang raja keturunan Sultan Sidi yakni saudara Sultan Sujak sebagaimana diutarakan dalam Sejarah Melayu. Meskipun tidak diketahui dengan pasti kapan tahun masuknya Islam ke Rokan, khususnya Rokan Hulu, namun pengembangan Islam khususnya di kerajaan-kerajaan lima luhak yakni Tambusai, Rambah, Kepenuhan, Rokan IV Koto dan Kunto Darussalam telah dikembangkan oleh penguasa-penguasa kerajaan dan muballigh-muballigh atau tokoh agama, kadi yang ada di kerajaan tersebut.

Islamisasi Rokan diprediksi berasal dari Barus yang menjadi bagian wilayah Tapanuli Tengah. Dari Tapanuli Tengah, penyebaran Islam dilanjutkan ke Tapanuli Selatan yang dikenal sebagai Serambi Mekahnya Sumatera Utara, di mana penduduk kabupaten ini 95\% adalah muslim. Tidak heran kalau pesantren, pondok-pondok hafidz, majlis-majlis pengajian tumbuh subur di sini.

Mengingat posisi Tapanuli Selatan berbatasan dengan daerah Riau tepatnya Rokan Hulu, maka sudah sangat mungkin Islam bersentuhan pula dengan masyarakat Rokan Hulu. Artinya proses masuknya Islam ke Rokan Hulu juga melalui perdagangan di samping adanya dakwah Islamiyah. Jalur yang digunakan ketika itu melalui Bukit Barisan. Hal ini diprediksi bahwa Riau dikenal sebagai penghasil lada dan rempahrempah. Pada masa lalu, kapur barus yang banyak di Barus dan rempah-rempah yang

\footnotetext{
${ }^{43}$ Tambusai, Hikayat Perjuangan Tuanku Tambusai, (Pekanbaru: Badan Pembinaan Kesenian Daerah Riau, 1978), h. 24.
} 
banyak di Riau merupakan komoditas perdagangan yang bernilai jual tinggi dan diperdagangkan sampai ke Arab dan Persia. Oleh karena itu, jika ditelusurui masuk dan berkembangnya Islam di Kerajaan-kerajaan Melayu, baik di luar Riau maupun di Riau sendiri, maka telah menjadi kesepakatan para sejarawan bahwa Islam masuk pada awalnya melalui jalur perdagangan yaitu pedagang-pedagang asing dari negeri-negeri Cina, India, Arab dan Persia.

Kapur Barus sangat harum dan menjadi bahan utama dalam pengobatan di daerah Arab dan Persia. Kehebatan kapur ini pun menjalar ke seluruh dunia dan mengakibatkan dia diburu dan harganya semakin tinggi. Demikian juga rempah-rempah yang banyak tumbuh subur di Riau mengakibatkan Riau juga didatangi oleh para pedagang Arab setelah mereka berada di Barus. Oleh karena itu sangat besar kemungkinan Islamisasi Riau berasal dari utara mengingat adanya hubungan para pedagang dengan masyarakat Riau. Sebagaimana yang dikatakan oleh Yusuf Abdullah Puar bahwa Riau terkenal dengan hasil rempah-rempahnya terutama sekali di daerah Kampar, Rokan dan Indragiri yang mempunyai potensi besar dalam menghasilkan rempah-rempah seperti lada, merica, kulit manis dan lain-lain. Jadi masuk dan datangnya agama Islam di daerah Riau tidak dapat dilepaskan dari perdagangan rempah-rempah itu karena hubungan dagang dengan Arab dan Persia telah berkembang sejak abad ke-6 Masehi. ${ }^{44}$

Lebih lanjut Yusuf Abdullah Puar mengatakan bahwa terjadinya hubungan dagang dikarenakan para pedagang tertarik untuk berhubungan langsung dengan penduduk di daerah Kampar, Indragiri dan Rokan, baik secara perdagangan maupun secara kontak pribadi. Hal ini dikarenakan sambutan masyarakat tempatan sangat menerima para pedagang tersebut. ${ }^{45}$ Dengan demikian, dapat dikatakan telah terjadi kontak langsung yang harmonis antara pedagang dengan masyarakat tempatan sehingga terjadi hubungan timbal balik bahkan terjadi perkawinan.

Dari Barus kontak perdagangan dilanjutkan ke daerah Rokan yang letaknya berdekatan dengan Barus. Lebih lanjut Yusuf Abdullah Puar mengatakan bahwa terjadinya hubungan dagang dikarenakan para pedagang tertarik untuk berhubungan langsung dengan penduduk di daerah Kampar, Indragiri dan Rokan, baik secara perdagangan maupun secara kontak pribadi. Hal ini dikarenakan sambutan masyarakat

\footnotetext{
${ }^{44}$ Yusuf Abdullah Puar, Masuknya Islam ke Indonesia, (Jakarta: CV. Indradjaja, 1984), h. 64.

${ }^{45}$ Ibid.
} 
tempatan sangat menerima para pedagang tersebut. ${ }^{46}$ Dengan demikian terjadi kontak langsung yang harmonis antara pedagang dengan masyarakat tempatan sehingga terjadi hubungan timbal balik bahkan terjadi perkawinan. Rokan diketahui menjadi negeri pemasok tenaga manusia sebagai pasukan Malaka saat hendak berperang. Selain itu, Bandar Rokan, Kampar, Inderagiri dan Siak merupakan lokasi-lokasi penting bagi Malaka, untuk menguasai jalur distribusi komoditas seperti emas, lada, gaharu, dan sebagainya dari Tanah Datar di Sumatera Barat menuju ke Selat Melaka. Setelah berhasil menjatuhkan Malaka, Portugis juga berusaha menguasai daerah di sepanjang Sungai Rokan dan Sungai Kampar.

Diprediksi kata Rokan berasal dari bahasa Arab "rakana” yang mengandung arti damai atau rukun. Diprediksi nama ini merupakan refleksi dari keadaan rakyat yang selalu rukun dan mementingkan kedamaian, baik dengan sesama penduduk negeri, maupun dengan orang luar negeri. Dari nama tersebut yang menunjukkan adanya pengaruh Arab. Dapat disimpulkan bahwa Kerajaan Rokan berdiri setelah Islam masuk ke kawasan tersebut

Pada lazimnya masuknya Islam terjadi dari dua arah, pertama dimulai dari kalangan atas yakni mengislamkan raja atau sultan beserta keluarganya. Hal ini menjadi salah satu faktor penting dari keberhasilan Islamisasi. Kedua, dimulai dari kalangan bawah seperti rakyat. Hal ini menjadi penting juga karena prilaku dan kepiawaian mubaligh dalam berdakwah membuat masyarakat kagum sehingga masyarakat tanpa ragu-ragu memeluk dan menerima Islam sebagai agama mereka. Selain itu kejujuran mereka dalam berdagang menjadi sebuah alasan logis untuk mendapatkan simpati rakyat. Oleh karena itu penyebaran Islam di Rokan Hulu tidak dapat dilepaskan dari aktivitas dakwah Islam. Aspek ini merupakan suatu proses yang sangat penting dalam sejarah Islmisasi Riau. Meskipun disadari bahwa terdapat banyak masalah yang perlu dikaji lagi secara kritis untuk memahami proses perkembangan Islam tersebut lebih komprehensif.

Pada pembahasan sebelum ini telah dijelaskan bahwa Kerajaan Rokan sudah wujud pada abad ke-14 Masehi. Hal ini tercatat dalam naskah Negara Kertagama. ${ }^{47}$ Kerajaan Rokan pada waktu itu diperintah oleh raja-raja yang sudah memakai gelar sultan. Dalam Sejarah Melayu, Raja Rokan adalah anak Sultan Sidi saudara Sultan

\footnotetext{
${ }^{46}$ Ibid.

${ }^{47}$ Slamet Mulyana, op.cit., h. 60.
} 
Sujak. Sedangkan agama Islam masuk ke Rokan dari Pasai melalui hubungan perdagangan yang mempertautkan antara kedua bandar perdagangan penting itu. ${ }^{48}$ Catatan ini ada benarnya karena sejak masa itu Islam sudah mulai masuk ke Rokan dan kedatangan Syarif Ali ke Batu Hampar bukanlah mewakili golongan penyebar agama Islam yang pertama di tanah Rokan. Tetapi beliau melanjutkan dakwah Islam di Batu Hampar yang kemungkinan masyarakatnya masih kuat menganut ajaran Hindu/Buddha meskipun sudah menerima Islam. Analisis terhadap berbagai batu nisan yang ada di komplek makam dapat menjelaskan bagaimana proses Islamisasi di Rokan, khususnya di Batu Hampar.

Tidak diketahui dengan pasti, siapa tokoh-tokoh yang dikuburkan di makam tersebut termasuk bahkan yang mana makam Datuk Batu Hampar juga belum diketahui secara pasti, karena tidak satupun terdapat tulisan pada batu nisan. Yang dilakukan hanya berupa prediksi saja sebab belum dikaji oleh arkeolog. Kemungkinan makam yang selama ini dikatakan sebagai makam Datuk Hampar yang diberi cungkup, berdasarkan pada kedudukannya yang lebih tinggi daripada makam-makam lainnya. Kemudian dari segi bentuk ukiran mungkin dapat diperkirakan jenis kelamin orang yang dikuburkan. Nisan bentuk dasar pipih yang utuh diperkirakan makam seorang perempuan karena terdapat ukiran berbentuk giwang (bulatan) pada kedua bahu nisan. Makam dengan jenis seperti ini dikenali sebagai makam permaisuri. Sementara nisan yang lain diperkirakan makam seorang lelaki karena berdasarkan kepada bentuknya yang seperti gada atau pemukul. Nisan jenis ini memang tidak mempunyai ukiranukiran yang melambangkan simbol kewanitaan. Oleh karena itu dikatakan sebagai nisan laki-laki.

Meskipun Islam telah masuk ke Rokan, namun tradisi Hindu-Buddha masih kuat diyakini oleh masyarakat Batu Hampar. Hal ini dapat dibuktikan dari bentuk dan ukiran pada batu nisan tersebut. Bentuk batu nisan jenis tersebut mempunyai ukiran timbul berbentuk bulatan pada nisan kaki. Ukiran ini melambangkan sebuah sinar yang dikenal dengan 'Sinar Majapahit.' Simbol seperti ini juga terdapat pada nisan-nisan Islam di Troloyo, Jawa Timur. Meskipun semua nisan jenis ini tidak terdapat tulisan yang menunjukkan angka tahun, diperkirakan usianya cukup tua. Apabila merujuk kepada nisan jenis yang sama pada makam Sultan Alauddin Said Maulana Abdul Aziz Syah di

${ }^{48}$ A. Samad Ahmad, Sulalatus Salatin (Sejarah Melayu), (Kuala Lumpur: Dewan Bahasa dan Pustaka, Kementrian Pelajaran Malaysia,1986), h. 82. 
Gampong Bandrong, Desa Bandar Kalifah, Peurelak, Aceh Timur, maka diperkirakan penggunaan nisan ini sudah lebih tua daripada nisan lainnya. Kerajaan Peurelak sudah berdiri sejak abad IX Masehi atau setidaknya sebelum Kerajaan Pasai abad XIII Masehi. Simbol 'Sinar Majapahit' itu sendiri mencerminkan bagaimana kuatnya pengaruh budaya Jawa atau Hindu/Budha pada masyarakat setempat sehingga harus diukirkan pada batu nisan orang yang meninggal. Hal ini bermakna bahwa pengaruh Majapahit benar-benar wujud di tanah Rokan sebagaimana disebut dalam Negara Kertagama. Memang sukar memastikan apakah orang yang dikubur dengan nisan jenis ini hidup pada abad ke-13-14 Masehi. Namun penggunaan batu nisan tersebut menunjukkan bagaimana sebuah proses Islamisasi terjadi dalam masyarakat yang masih kuat memegang tradisi pra-Islam. Artinya penduduk telah memeluk agama Islam yang dibawa oleh Syarif Ali atau orang lain sebelumnya sedangkan masyarakat setempat masih kukuh mempertahankan tradisi Hindu/Budha. Dengan demikian penetrasi Islam melalui golongan bangsawan atau raja-raja akan mempercepat perkembangan Islam di Rokan. Dari sudut pandang ini, sangat mungkin Kerajaan Rokan Islam merupakan kelangsungan dari Kerajaan Rokan Hindu-Buddha.

\section{E. Penetrasi Islam terhadap Pendidikan Keagamaan Masyarakat di Rokan Hulu}

Islam adalah agama rahmatan lilalamin yang menugaskan umatnya untuk menyebarluaskan dan menyiarkan ajaran Islam kepada seluruh umat manusia. Islam dapat menjamin wujudnya kebahagiaan dan kesejahteraan umat manusia, bilamana ajaran Islam yang mencakupi segenap aspek kehidupan itu dijadikan sebagai panduan hidup dan dilaksanakan secara menyeluruh dan sungguh-sungguh. Menurut Jamaluddin Rabain, bahwa Islam adalah agama dakwah. Dakwah dapat diartikan sebagai suatu kegiatan ajakan, baik dalam bentuk lisan, tulisan, tingkah laku dan sebagainya yang dilakukan secara sadar dan terencana dalam usaha mempengaruhi orang lain, baik secara sendiri maupun berkelompok supaya timbul dalam dirinya suatu pengertian, kesadaran dan sikap penghayatan terhadap ajaran Islam sebagai pesan yang disampaikan kepadanya tanpa ada unsur paksaan. ${ }^{49}$ Artinya, penyebaran Islam di Nusantara tidak dapat dilepaskan dari aktivitas dakwah. Oleh karena itu, Islamisasi

\footnotetext{
${ }^{49}$ Jamaluddin Rabain, "Aktifitas Dakwah Kepada Masyarakat Terasing Suku Talang Mamak," dalam Kutubkhanah Jurnal Penelitian Sosial Keagamaan, Vol. 8, No. 1, Juni 2006, ISSN:1693-8186, Pekanbaru: LPP UIN Suska Riau, h.67.
} 
dalam masyarakat Melayu pada dasarnya tidak pernah berlangsung secara sekaligus akan tetapi berlangsung secara berangsur-angsur dan terus menerus sesuai dengan dakwah yang diterima masyarakat.

Berkaitan dengan penetrasi Islam di Rokan Hulu, maka akan muncul berbagai dampak bagi masyarakatnya karena sebelum Islam, masyarakatnya sudah mempunyai keyakinan. Namun dengan datangnya agama Islam, maka keyakinan lama berubah kepada keyakinan baru tanpa ada paksaan oleh siapapun. Artinya kedatangan agama Islam membawa perubahan bagi kehidupan masyarakat Rokan Hulu karena terjadi penyatuan dua keyakinan yakni keyakinan yang datang dan keyakinan yang menyambut. Dalam hal ini penetrasi Islam berjalan dengan damai tanpa ada kekerasan karena agama Islam membawa misi kedamaian dan keselarasan hidup, bukan saja antar manusia tetapi juga antar sesama makhluk Tuhan. Namun menurut Husni Thamrin dalam tataran historisnya misi agama tidak selalu artikulatif. Selain sebagai alat pemersatu sosial, agama pun menjadi unsur konflik. Mungkin pernyataan ini agak berlebihan, tetapi jika melihat perjalanan sejarah dan realitas di muka bumi ini pernyataan itu menemukan landasan historisnya sampai sekarang. ${ }^{50}$

Pernyataan di atas tidak terjadi pada masyarakat Melayu di Rokan Hulu dalam menerima Islam sebagai keyakinannya, di mana masyarakat Rokan Hulu dengan cepat dapat berintegrasi dengan dakwah Islamiyah. Meskipun sebelum Islam, masyarakat Melayu Rokan Hulu telah menyakini Hindu dan Budha serta kepercayaan lainnya seperti animisme dan dinamisme. Namun kehadiran Islam telah mampu memberi warna dalam kehidupan masyarakat Melayu Rokan Hulu yang tentu saja melalui proses akulturasi dan adaptasi antara nilai-nilai Islam dengan kebudayaan lokal. Artinya masyarakat mengalami perubahan dalam kehidupan dari segala aspek. Fenomena dan ekspresi kebudayaan Islam pada masyarakat Melayu di Rokan Hulu telah berakomodasi sedemikian rupa sehingga Islam sebagai acuan hidup memang banyak memberikan norma-norma dan aturan tentang kehidupan dibandingkan dengan agama lain. Dengan demikian antara Islam dan masyarakat Rokan Hulu terjadi keselarasan, aman dan damai. Hal ini terlihat pada simbol ungkapan yang hidup di Alam Melayu "Melayu identik Islam.” Orang Melayu akan mengatakan bahwa agama Islam itu dapat dipakai

50 Thamrin, "Agama, Politik dan Kekerasan," dalam Kutubkhanah Jurnal Penelitian Sosial Keagamaan, Vol. 10, No. 1, Januari-Juni 2007, ISSN:1693-8186, Pekanbaru: LPP UIN Suska Riau, h. 1. 
untuk hidup dan dapat ditumpangi untuk mati. Artinya bahwa agama Islam dengan segala aspeknya dapat dipakai untuk menyelesaikan persoalan hidup.

Masyarakat Melayu Rokan Hulu yang notabenenya masyarakat yang menganut ajaran Islam secara jelas dipengaruhi oleh sistem nilai Islam dan selanjutnya akan mempengaruhi pula terhadap pandangan hidup masyarakatnya. Bila dilihat proses akulturasi Islam dengan masyarakat Rokan Hulu melahirkan apa yang dikenal dengan local genius. Menurut Hartati Soebadio, yang dikutip Hasbullah, bahwa local genius yaitu kemampuan menyerap sambil mengadakan seleksi dan pengolahan aktif terhadap pengaruh kebudayaan asing sehingga dapat dicapai suatu ciptaan baru yang unik yang tidak terdapat di wilayah bangsa yang membawa pengaruh budayanya. ${ }^{51}$ Dalam hal ini penetrasi Islam terhadap pendidikan keagamaan masyarakat di Rokan Hulu terlihat pada sosial keagamaan yang tumbuh dan berkembang di Rokan Hulu di antaranya tumbuh dan berkembangnya tarekat Naqsyabandiyah.

\section{Tumbuh Subur Tarekat Naqsyabandiyah di Rokan Hulu}

Keberadaan Islam yang datang dari Jazirah Arab telah membawa perubahan yang cepat dalam alam pikiran dunia Melayu. Oleh karena itu kedatangan agama Islam adalah membawa perubahan terhadap segala aspek kehidupan orang Melayu. Dalam aspek pendidikan, masyarakat Melayu di Rokan Hulu amat dipengaruhi oleh sistem pendidikan Islam yang bersandarkan kepada al-Qur'an dan al-Hadits yang diperkenalkan oleh para ulama yang datang menyebarkan agama Islam, baik secara khusus maupun sambil berdagang. Kebanyakan para ulama menyiarkan agama Islam ke Nusantara datang dari negara Timur Tengah. Sebagaimana yang telah dijelaskan sebelum ini bahwa Barus merupakan pelabuhan terbesar pada masanya dan merupakan daerah yang amat dikenal oleh pedagang di Timur Tengah. Dengan demikian, para pedagang sekaligus seorang ulama akan melakukan dakwah Islamiyah sesuai dengan aliran yang berasal dari penyebarnya sehingga pada akhirnya masyarakat Rokan Hulu juga mendapat tempias aliran yang dibawa oleh penyebar tersebut. Misalnya saja di Rokan Hulu sangat berkembang dengan pesat tarekat naqsabandiyah. Sedangkan tarekat Naqabandiyah yang tumbuh subur pada masyarakat Rokan Hulu merupakan nama tarekat yang disandarkan kepada nama pendirinya yaitu Syekh Muhammad bin

51 Hasbullah, "Dialektika Islam dalam Budaya Lokal: Potret Budaya Melayu Riau," dalam Jurnal Sosial Budaya, Vol. 11, No. 2, Juli-Desember 2014, h. 144-269, ISSN: 1979-2603, (Pekanbaru: LPPM UIN Suska Riau, 2015), h. 176. 
Muhammad Bahauddin Bukhari al-Naqsyabandy yang terkenal dengan sebutan Syekh al-Naqsyabandy. ${ }^{52}$

Secara etimologis tarekat berasal dari bahasa Arab “ طرق- يطرق-طريقا-طريقة yang berarti "jalan, haluan atau mazhab." Dalam Ensiklopedi Islam, pengertian tarekat memiliki tujuh arti, yaitu (1) jalan, cara, "الكيفية" (2) metode, sistem, "الأسلوبة" (2) mazhab, aliran, haluan, “المذهب" (5) pohon kurma yang tinggi,

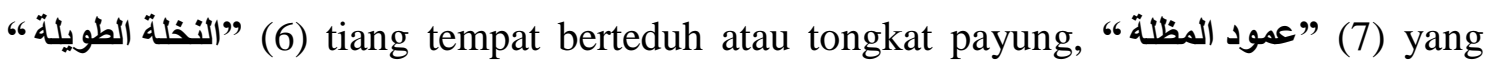
mulia, terkemuka dari suatu kaum,“" 5alam literatur Barat menurut Gibb, kata thariqat menjadi tarika yang berarti road (jalan raya), way (cara), dan pathlm (jalan setapak). Road atau jalan raya merupakan jalan besar yaitu syari'at, sedangkan pathlm atau jalan setapak adalah jalan kecil, yang secara khusus ditujukan kepada tarekat atau perjalanan spiritual. ${ }^{54}$ Dari beberapa pengertian tersebut dapat dikatakan bahwa arti tarekat memiliki multi-makna, yang kesemuanya dikonotasikan pada pemaknaan yang sesuai dengan pengamalan, aturan dan tujuan bertarekat itu sendiri.

Tarekat secara terminologi berarti perjalanan seorang salik menuju Tuhan dengan cara menyucikan diri atau dapat mendekatkan diri sedekat mungkin kepada Tuhan. ${ }^{55}$ Sebagai jalan yang ditempuh untuk mendekatkan diri kepada Tuhan, orang yang melakukan tarekat tidak dibenarkan meninggalkan syari'at.

Apabila ditelusuri mengenai keberadaan tarekat yang diyakini oleh masyarakat Melayu di Rokan Hulu sangat bersesuaian dengan proses Islamisasi di Nusantara yang terjadi pada abad ketujuh Masehi melalui para pedagang yang sebagiannya melakukan transaksi dagang di pelabuhan Barus di bagian barat pulau Sumatera. Hal ini dapat disandingkan dengan kemunculan tarekat yang dilahirkan oleh para sufi. Menurut Suhayib, tarekat diperkirakan mulai muncul pada abad keenam dan ketujuh hijrah dimana para sufi mulai mengembangkan pemahaman yang menjadi alirannya. ${ }^{56}$ Misalnya Ahmad al-Rifa'i (w. 570 H.), Abd al-Qadir al-Jailani (w. 651 H.), Abu alSazzili (w. 656 H). Kemudian Abu al-Abbas al-Mursi (w. 686 H.), Ibnu 'Atha'illah al-

\footnotetext{
${ }^{52}$ Imron Abu Umar, Sekitar Masalah Thariqat Naqsyabandiyah, (Kudus: Menara, 1980), h. 26.

${ }^{53}$ Dewan Ensiklopedi, Ensiklopedi Islam, Jilid 5, (Jakarta: Ikhtiar Baru Van Hoeve, 1993), h. 66.

${ }^{54}$ H.A.R. Gibb, Shorter Encyclopedia of Islam, (Leiden: E.J. Brill, 1974), h. 573. Lihat juga Mulyadhi Kartanegara, Menyelami Lubuk Tasawuf, (Jakarta: Erlangga, 2006), h.15.

${ }^{55}$ Dewan Ensiklopedi, Ensiklopedi Islam, Jilid IV, (Jakarta: Ikhtiar Baru van Hove, 1993), Cet. 1.

${ }^{56}$ Suhayib, Pengaruh Pemikiran Tasawuf Said Nursi dalam Pemberdayaan Politik (Al-Tamkin al-Siyasi) di Turki (Studi atas Kitab Majmu'ah al-Maktubat), Disertasi yang tidak diterbitkan, (Pekanbaru: PPS UIN Suska Riau, 2017), h. 111.
} 
Sakandari (w. $709 \mathrm{H}$ ) dan lain-lainnya. ${ }^{57}$ Pada periode inilah kata tarekat pada para sufi mutakhir dinisbatkan bagi sejumlah pribadi sufi yang bergabung dengan seorang guru (syaikh) dan tunduk di bawah aturan-aturan terinci dalam jalan ruhani. Mereka hidup secara kolektif di berbagai zawiah, rabath dan khanaqah (tempat-tempat latihan) atau berkumpul secara periodik dalam acara-acara tertentu serta mengadakan berbagai pertemuan ilmiah maupun ruhaniah yang teratur. ${ }^{58}$

Sebagai suatu norma bagi masyarakat Melayu Rokan Hulu, ajaran Islam telah menjadi pola anutan masyarakat. Dalam konteks inilah Islam sebagai agama sekaligus telah menjadi panutan masyarakat Rokan Hulu sehingga secara praktis tarekat yang tumbuh dan berkembang di Rokan Hulu dapat dipahami sebagai sebuah pengamalan keagamaan yang bersifat esoterik (penghayatan) yang dilakukan oleh seorang muslim dengan menggunakan amalan-amalan berbentuk wirid dan zikir yang diyakini memiliki mata rantai secara sambung menyambung dari guru mursyid ke guru mursyid lainnya sampai kepada Nabi Muhammad SAW. dan bahkan sampai Jibril dan Allah SWT. Para pengikutnya bermula dari pengikut biasa (mansub) menjadi murid kemudian menjadi pembantu syaikh (khalifah) dan akhirnya jika memungkinkan bisa menjadi seorang guru yang mandiri (mursyid). Kesinambungan ini dikenal di kalangan tarekat dengan nama silsilah (transmisi). Dalam tataran ini tarekat menjadi sebuah organisasi ketasawufan. ${ }^{59}$

Secara umum ajaran dasar tarekat Naqsyabandiyah yang diamalkan masyarakat adalah: (1) Husy dar dam, (sadar sewaktu bernafas) merupakan suatu latihan konsentrasi di mana seseorang harus menjaga diri dari kehilafan dan kealpaan ketika keluar masuk nafas, serta berhati-hati dan senantiasa merasakan kehadiran Allah. Latihan seperti itu dimaksudkan untuk memberikan kekuatan spiritual dan membawa orang lebih dekat kepada Allah; (2) Nazhar bar qadam, (menjaga langkah). Maksudnya adalah seorang murid yang sedang menjalani khalwat suluk, bila berjalan harus menundukkan kepala, dengan melihat ke arah kaki. Ketika duduk, tidak melihat ke kiri atau ke kanan, karena menurut ajaran tarekat ini, memandang kepada aneka ragam ukiran dan warna dapat melalaikan orang dari mengingat Allah. Selain itu, menurut ajaran tarekat ini ditujukan supaya tujuan-tujuan yang (rohaniahnya) tidak dikacaukan

\footnotetext{
${ }^{57}$ Ira M. Lapidus, Sejarah Sosial Umat Islam, Terj. Ghufron A. Mas'adi, (Jakarta: Raja Grapindo Persada, 2000), h. 261.

${ }^{58}$ Ibid., h. 235.

${ }^{59}$ Martin van Bruinessen, Tarekat Naqsyabandiyah di Indonesia, (Bandung: Mizan, 1996), h. 15.
} 
oleh segala hal yang berada di sekelilingnya; (3) Safat dan wathan, (melakukan perjalannya di tanah kelahirannya). Maknanya adalah melakukan perjalanan bathin dengan meninggalkan segala bentuk ketidaksempurnaannya manusia menuju kesadaran akan hakikatnya sebagai makhluk yang mulia; (4) Khalwat dar anjuman, (sepi di tengah keramaian). Khalwat diartikan pada menyepinya seseorang pertapa, sementara anjuman dapat berarti perkumpulan tertentu. Dalam ajaran tarekat ini khalwat terbagi dua yakni (a) khalwat lahir, di mana orang yang bersuluk mengasingkan diri ke sebuah tempat tersisih dari masyarakat ramai; (b) khalwat batin, di mana mata hati menyaksikan rahasia kebesaran Allah dalam pergaulan sesama makhluk; (5) Yad krad, (ingat atau menyebut). Maksudnya adalah berzikir secara terus menerus untuk mengingat Allah, baik zikir ism al-zat (menyebut Allah) maupun zikir nafi itsbat (menyebut la ilaha illa Allah). Bagi kaum Naqsyabandiyah, zikir tidak hanya terbatas dilakukan secara berjamaah saja tetapi juga ketika sendirian setelah shalat, yang dilakukan secara terus menerus supaya di dalam hati bersemayam kesadaran akan Allah yang permanen; (6) Baz Gasht, (kembali, memperbaharui). Melakukan perbuatan ini ditujukan untuk mengendalikan hati agar tidak condong pada hal-hal yang menyimpang. Sesudah menghela (melepaskan) nafas, orang yang berzikir itu kembali munajat dengan mengucapkan kalimat yang mulia Ilahi anta maqshudi wa ridhaka mathlubi (ya Tuhanku, Engkaulah tempatku memohon dan keridhaan-Mu-lah yang ku harapkan). Dalam prakteknya atau sewaktu melaksanakan zikir, makna dari kalimat ini harus senantiasa berada di hati seseorang, dan mengarahkan perasannya yang paling halus kepada Allah semata, hingga terasa dalam kalbunya rahasia tauhid yang hakiki dan semua makhluk ini lenyap dari pandangannya; (7) Nigah Dasyt, (waspada). Maksudnya adalah setiap murid harus menjaga hati, fikiran dan perasaan dari sesuatu walau sekejap ketika melakukan zikir tauhid. Hal itu ditujukan untuk mencegah pikiran dan perasaan agar tidak menyimpang dari kesadaran yang tetap akan Tuhan, di samping untuk memelihara fikiran dan prilaku agar sesuai dengan makna kalimat tersebut; (8) Yad dasyt, (mengingat kembali), maksudnya adalah tawajuh (menghadapkan diri) kepada nur zat Yang Maha Esa, tanpa berkata-kata. Secara hakikat adalah menghadapkan diri dan mencurahkan perhatian kepada nur zat Allah itu tiada lurus kecuali sesudah fana (hilang kesadaran diri) yang sempurna. Semula hal ini dikaitkan pada pengalaman lansung akan kesatuan zat yang ada (wahdat al-wujud). Oleh Ahmad Sirhindi dan 
Ellya Roza, Yasnel: Penetrasi Islam dalam Pendidikan Keagamaan...

pengikut-pengikutnya bahkan mengemukakan dalil adanya tingkat yang lebih tinggi. Tingkat tinggi yang dimaksud adalah di mana seorang sufi sadar bahwa kesatuan (kemanunggalan) ini hanyalah bersifat fenomenal, bukan ontologis (wahdat alsyuhud). ${ }^{60}$

Perlu diketahui bahwa kitab pegangan Naqsyabandiyah pada umumnya mengantarkan sang murid untuk mengucapkan kalimat zikir dalam hati sebelum memulai zikir ism al-dzat dan mengucapkannya sekali lagi di antara zikir tauhid yang berurutan. Sebagaimana Syekh Abu Bakr al-Kattani berkata: "Saya menjaga pintu hatiku selama 40 tahun. Tidak ku bukakan selain hanya kepada Allah, sehingga jadilah hatiku tidak mengenal seorang selain Tuhan.”

Ajaran dasar tarekat Naqsyabandiyah menurut Muhammad Amin al-Kurdi dalam kitabnya, Tanwir al-Qulub, seperti yang dikutip oleh Fu'ad terdiri dari 11 asas, di mana delapan asas dirumuskan oleh Abd al-Khaliq Ghujdwani, sedangkan tiga asas lainnya yang ditambah oleh Muhammad Baha' al-Din Naqsyabandi.

\section{Tumbuh Subur Surau-surau Suluk}

Masyarakat Melayu Rokan Hulu adalah pemeluk agama Islam. Budaya Islam terlihat kental dalam tradisi adat dan budaya suku Melayu Rokan Hulu. Agama Islam masuk ke kalangan suku Melayu Rokan Hulu membawa perubahan terhadap pendidikan keagamaan masyarakatnya sehingga bermunculan rumah-rumah ibadah dan surau-surau tempat mempelajari agama Islam bagi masyarakat. Hal ini merupakan aplikasi dari icon Rokan Hulu sebagai "negeri seribu suluk."

Secara etimologis kata "suluk" berarti jalan atau cara, bisa juga diartikan kelakuan atau tingkah laku sehingga husn al-suluk bermakna kelakuan yang baik. Kata "suluk" adalah mashdar yang diturunkan dari bentuk verbal salaka - yasluku yang secara harfiah mengandung beberapa arti yaitu memasuki, melalui jalan, bertindak dan memasukkan. Seseorang yang menempuh jalan ini disebut salik. Sedangkan secara terminologi, kata "suluk" merupakan pemaknaan yang berasal dari al-Qur`an yang tertulis pada surat al-Nahl ayat 69 yang berbunyi sebagai berikut:

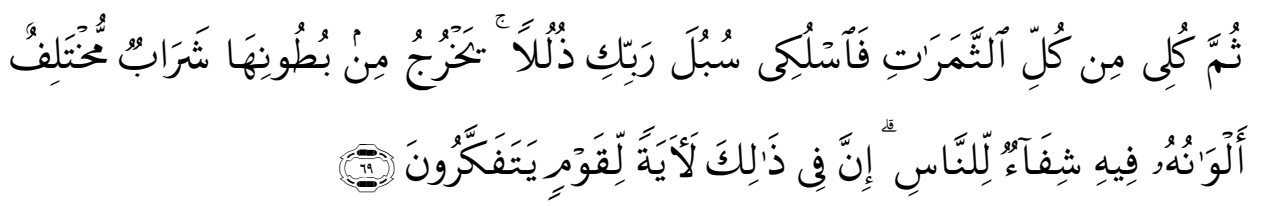

\footnotetext{
${ }^{60}$ Sri Mulyati, op.cit., h. 102-105.
} 
"Kemudian makanlah dari tiap-tiap (macam) buah-buahan dan tempuhlah jalan Tuhanmu yang telah dimudahkan (bagimu). Dari perut lebah itu keluar minuman (madu) yang bermacam-macam warnanya, di dalamnya terdapat obat yang menyembuhkan bagi manusia. Sesungguhnya pada yang demikian itu benarbenar terdapat tanda (kebesaran Tuhan) bagi orang-orang yang memikirkan."

Dalam memahami tasawuf, suluk diartikan sebagai perjalanan spiritual menuju Sang Sumber. Ini adalah metode perjalanan melalui berbagai keadaan dan kedudukan. Menurut Al-Gazali, suluk adalah menjernihkan akhlak, amal dan pengetahuan. Suluk dilakukan dengan cara aktif berkecimpung dengan amal lahir dan amal batin. Semua kesibukan hamba dicurahkan kepada Tuhannya dengan membersihkan batinnya untuk persiapan wushul kepadaNya. ${ }^{61}$ Sementara itu Ghufran F. Mas'adi, mengatakan bahwa suluk merupakan keadaan jiwa atau tindakan kalangan sufi yang dipandang sebagai sebuah perjalanan kepada Tuhan. Istilah ini juga menunjukkan pada sebuah quasi magis dan sebuah ucapan spritualis yang bercorak lokal Indonesia dikenal sebagai upacara suluk. Dalam upacara ini pelakunya berusaha mencapai kekuatan psikis atau magis dengan mempertahankan diri dari serangan dunia spirit selama satu malam yang mana seseorang dimatikan secara simbolik. ${ }^{62}$ Artinya, suluk merupakan kegiatan seseorang untuk menuju kedekatan diri kepada Allah. Suluk berarti menempuh jalan (spiritual) untuk menuju Allah. Menempuh jalan suluk mencakup seluruh disiplin seumur hidup dalam melaksanakan aturan-aturan eksoteris agama Islam secara syariat sekaligus aturan-aturan agama Islam secara hakikat.

Dalam arti yang luas, suluk hampir sama dengan tarekat yakni cara mendekatkan diri kepada Tuhan. Hanya saja kalau terekat masih bersifat konseptual sedangkan suluk sudah dalam bentuk teknis operasional. Oprerasional dalam arti yang sesungguhnya bukan hanya sekedar teori melainkan langsung dipraktikkan dalam tingkah laku keseharian. ${ }^{63}$ Demikian halnya di Rokan Hulu yang dikenal dengan "negeri seribu suluk," di mana sebutan tersebut sangat bersesuaian dengan kondisi pendidikan keagamaan yang terjadi pada masyarakat, di mana kehidupan masyarakat selalu diwarnai oleh tempat-tempat atau rumah-rumah i'tikaf yang banyak terdapat dan didirikan bahkan mendapat dukungan dari pihak pemerintah. Biasanya masyarakat

\footnotetext{
${ }^{61}$ Al-Ghazali, Taman Jiwa kaum Sufi, Terj. Abu Hamid, (Surabaya: Risalah Gusti, 1994).

${ }^{62}$ Dewan Ensiklopedi, loc.cit.,

${ }^{63}$ Mustafa Zahri, Kunci Memahami Ilmu Tasawuf, (Surabaya: Bina Ilmu, 1979), h. 23.
} 
Ellya Roza, Yasnel: Penetrasi Islam dalam Pendidikan Keagamaan...

melakukan suluk dan beri'tikaf di masjid sebagaimana yang dicontohkan oleh Rasulullah SAW. Masyarakat Melayu Rokan Hulu melakukan suluk di surau-surau dengan waktu suluk dilaksanakan yang tidak sama. Misalnya ada yang selama 10 hari, ada yang 20 hari, dan ada pula yang 40 hari. Peserta suluk atau jamaah suluk itu wajib di bawah pimpinan seseorang yang telah ma'rifat, dalam hal ini adalah syekh mursyid.

Apabila dilihat ke belakang mengenai kondisi keagamaan masyarakat Melayu di Rokan Hulu memang sepantasnya dijuluki "negeri seribu suluk," sebab Allah SWT telah melahirkan tokoh-tokoh tasawuf yang kewara'an dan karomahnya sangat luar biasa tidak hanya dikenal dalam konteks nasional bahkan sudah mendunia. Misalnya Syekh Abdul Wahab Rokan, Syekh Ismail dan syekh-syekh lainnya. Mereka telah memberikan warna khusus pada masyarakat Melayu Rokan Hulu sehingga kehidupan keagamaan masyarakat tidak lepas dari pengaruh mereka sehingga di Kabupaten Rokan Hulu amat banyak berdiri surau-surau suluk yang tersebar di seluruh desa yang ada di 16 kecamatan. Misalnya Surau Suluk Al-'Arif Dusun Pasir Jambu Desa Rambah Tengah Hilir Kecamatan Rambah yang dipimpin oleh Tuan Guru Nasir Khalifah Al'Arif, kemudian ada Surau Suluk Baiturrohim yang dipimpin oleh Khalifah Umar. Dengan berdirinya surau-surau suluk tersebut dapat menjadi salah satu simbol kekuatan umat Islam di bidang pendidikan keagamaan Islam karena tarekat Naqsyabandiyah dikenal memiliki warna dan tata cara yang bervariasi akan tetapi penganut tarekat ini konsisten dengan asas atau ajaran dasarnya sama yang dijadikan sebagai acuan atau pegangan. Tiga ajaran dasarnya itu berasal dari Syekh Baha`al-Din Naqsyabandi adalah (1) Wuquf zamani, memeriksa penggunaan waktu. Maksudnya adalah orang yang bersuluk senantiasa selalu mengamati dan memperhatikan dengan teratur keadaan dirinya setiap dua atau tiga jam sekali. Apabila ternyata keadaannya secara terus menerus sadar dan tenggelam dalam zikir dan melakukan yang terpuji, maka ia hendaklah bersyukur kepada Allah. Sebaliknya jika seseorang keadaannya dalam kealpaan atau dan melakukan perbuatan dosa, maka ia harus segera minta ampun dan bertaubat kepada Allah, serta kembalikan hatinya pada kehadiran hati yang sempurna; (2) Wuquf adadi, memeriksa hitungan zikir. Maksudnya adalah dengan penuh hati-hati (konsentrasi penuh) memelihara bilangan ganjil zikir nafi itsbat, 3 atau 5 sampai 21 kali; (3) Wuquf qalbi, menjaga hati tetap terkontrol. Maksudnya adalah kehadiran hati serta kebenaran tiada yang tersisa, sehingga perhatian seseorang secara sempurna 
sejalan dengan zikir dan maknanya selain kebenaran Allah yang tiada menyimpang dari makna dan perhatian zikir. Dan dikatakan juga bahwa hati orang yang berzikir berhenti (wuquf) menghadap Allah dan bergumul dengan lafaz-lafaz dan makna zikir.

Itulah ajaran dasar yang harus diamalkan oleh kaum Naqsyabandiyah dalam kegiatannya di samping kegiatan-kegiatan yang lainnya. Selain ajaran dasar seperti yang telah dijelaskan di atas, dalam ajaran tarekat Naqsyabandiyah titik berat amalan penganutnya adalah zikir. Zikir yang dimaksud adalah dengan berulang-ulang menyebut nama Allah atau menyatakan kalimah La ilaha illa Allah (Tiada Tuhan selain Allah), dengan tujuan untuk mencapai kesadaran akan Allah yang lebih lansung dan permanen. Zikir yang dilakukan kaum Naqsyabandiyah pada umumnya adalah zikir khafi (diam, tersembunyi) secara berkesinambungan pada waktu pagi, sore, siang, malam, duduk, berdiri, di waktu sibuk ataupun di waktu senggang. ${ }^{64}$

Dalam proses penetrasi Islam dengan masyarakat, menurut Husni Thamrin ada yang perlu dicermati oleh pemeluk suatu agama, baik perorangan maupun berkelompok yakni (1) ideologi isolasi; (2) ideologi permusuhan; (3) ideologi kompetisi; dan (4) ideologi kemitraan. Ideologi-ideologi tersebut muncul karena adanya kesadaran terhadap bahaya skularisme sehingga agama-agama secara bersama-sama menghadapi bahaya tersebut. ${ }^{65}$ Berdasarkan dengan hal tersebut, dapat dikatakan bahwa telah terjadi penetrasi Islam selain dengan sosial budaya masyarakat Melayu Rokan Hulu juga terjadi dalam sosial keagamaan yang diimplementasikan dalam kehidupan sehari-hari karena Islam adalah budaya masyarakat dan budaya masyarakat adalah Islam. Islam sebagai sebuah agama yang universal tidak mempunyai hambatan dalam berintegrasi dan berasimilasi dengan masyarakat tempatan yang telah lebih dahulu memiliki keyakinan beragama. Oleh karena itu Islam dianggap sebagai komponen utama budaya Melayu karena agama Islam dan budaya Melayu sudah bersebati dalam kehidupan sehari-hari orang Melayu. Artinya masuk dan berkembangnya Islam di dunia Melayu mengambil pola tradisi integrative, di mana agama menyatu dengan adat dan budaya.

\footnotetext{
${ }^{64}$ Baha' al-Din dipercaya mendapat pelajaran lansung secara rohaniah dari 'Abd al-Khaliq. Pelajaran ini khususnya menyangkut zikir khafi, yang tidak dipraktekkan oleh semua pengikutnya. Perlu juga diketahui, walaupun zikir ini dipercaya berasal dari Abu Bakar Shiddiq, dalam perjalanannya zikir ini oleh Yusuf al Hamadani telah menggabungkannya dengan zikir keras. Atas kondisi ini juga yang melatar belakangi di antara kaum Naqsyabandiyah ada yang melakukannya. Selain hal itu perlu juga dicatat bahwa dalam pandangan Naqsyabandiyah, pelajaran yang diberikan 'Abd al-Khaliq kepada Baha al-Din menjadikan zikir diam sebagai norma dalam tarekat Naqsyabandiyah. Lihat Sri Mulyati, op. cit., h. 105-106.

${ }^{65}$ Thamrin, "Agama dalam Masyarakat Majemuk," dalam Kutubkhanah Jurnal Penelitian Sosial Keagamaan, Vol. 10, No. 2, Juli-Desember 2007, ISSN:1693-8186, (Pekanbaru: LPP UIN Suska Riau, 2007), h.128.
} 


\section{F. Kesimpulan}

Berdasarkan penelitian yang telah dilakukan, maka pada akhir penulisan ini disampaikan kesimpulan sebagai jawaban dari permasalahan yang dirumuskan pada pendahuluan. Kesimpulan tersebut adalah sebagai berikut:

1. Pola penetrasi Islam yang berlangsung pada jalur utara Riau pada umumnya adalah melalui perdagangan meskipun ada juga dalam bentuk perkawinan dengan penduduk tempatan sehingga membentuk komunitas muslim. Oleh karena itu, dapat dikatakan bahwa Islam adalah agama dakwah yang diartikan sebagai suatu kegiatan ajakan, baik dalam bentuk lisan, tulisan maupun tingkah laku yang dilakukan secara sadar dan terencana dalam usaha mempengaruhi orang lain, baik secara sendiri maupun berkelompok agar timbul kesadaran dan sikap penghayatan terhadap ajaran Islam tanpa ada unsur paksaan. Artinya Islamisasi jalur utara Riau terjadi dalam bentuk integrasi tradisional.

2. Penetrasi Islam dalam pendidikan keagamaan masyarakat Melayu Rokan Hulu teraplikasi kepada sebutan "negeri seribu suluk." Sebab bagi masyarakat Rokan Hulu agama Islam itu dapat dipakai untuk hidup dan dapat ditumpangi untuk mati. Artinya agama Islam dengan segala aspeknya dapat dipakai untuk menyelesaikan persoalan hidup karena agama Islam membawa misi kedamaian dan keselarasan hidup bukan saja antar manusia tetapi juga antar sesama makhluk Tuhan.

3. Pendidikan keagamaan masyarakat Rokan Hulu terlihat pada tarekat Naqsyabandiyah yang tumbuh subur di seluruh desa di wilayah Rokan Hulu bahkan telah pula melahirkan tokoh, ulama, pemimpin tarekat Naqsyabandiyah yang mendunia seperti Syekh Abdul Wahab Rokan dan lain-lain.

\section{G. Referensi}

Abdullah Abbas Nasution, Syarahan, Makalah, yang disampaikan di UKM Malaysia pada tanggal 21-24 Februari 1978 dan tidak diterbitkan. Kedah: Pustaka Nasution, 1978

Abu Bakar, "Pemanfaatan Masjid dalam Membina Umat." Kutubkhanah Jurnal Penelitian Sosial Keagamaan, Vol. 10, No. 1, Januari-Juni 2007, ISSN:16938186, Pekanbaru: LPP UIN Suska Riau

Al-Ghazali, Taman Jiwa Kaum Sufi, Terj. Abu Hamid, Surabaya: Risalah Gusti, 1994 
A. Samad Ahmad, Sulalatus Salatin (Sejarah Melayu), Kuala Lumpur: Dewan Bahasa dan Pustaka, Kementrian Pelajaran Malaysia, 1986

Azyumardi Azra, Jaringan Ulama Timur Tengah dan Kepulauan Nusantara Abad XVIIXVIII: Melacak Akar-akar Pembaharuan Pemikiran Islam di Indonesia. Bandung: Mizan, 1994

--------, Renaissance Islam di Asia Tenggara, Bandung: Mizan.

-, Pendidikan Islam: Tradisi dan Modernisasi Menuju Milenium Baru, Jakarta: Logos, 1999

A. Hasymi, Sejarah Masuk dan Berkembangnya Islam di Indonesia, Banda Aceh: Almaarif, 1993, Cet. ke-3

A.H. Hil. (pnyl), "Hikayat Raja-raja Pasai,” JMBRAS, No. 33, 1960

A.W. Munawir, Kamus Arab Al-Munawwir Arab-Indonesia, Yogyakarta: Pustaka Progresif, 1984

Budi Sulistiono, "Islam dan Tamadun Melayu: Menatap Masa Depan," Jurnal Sosial Budaya, Vol. IX. No.1, (104-114), ISSN.1979-2603, Pekanbaru: LPPM UIN Suska Riau, 2014

Claude Gulliot, Lobu Tua: Sejarah Awal Barus, Terj. Daniel Perret, Jakarta: Ecole Francaise d'extreme-orient Association Archipel, Pusat Penelitian Arkeologi, Yayasan Obor Indonesia, 2002

Christopher Liod, Explanation in Social History, New York: Basic Blackwell Inc, 1986

Dewan Ensiklopedi, Ensiklopedi Islam, Jilid IV, Jakarta: Ikhtiar Baru van Hove, 1993

Edward Hellet Carr, What is History, Terj. Abdur Rahman Haji Ismail, Kuala Lumpur: Dewan Bahasa dan Pustaka Kementerian Pelajaran Malaysia, 1984

Ellya Roza, dkk, Babul Qawa'id, Transliterasi dan Analisis, Pekanbaru: Pemda Siak, 2002.

--------, "Hubungan Arkeologi dalam Kajian Filologi," Husni Thamrin (ed). Arkeologi Islam Nusantara, Pekanbaru: LPP UIN Suska Riau, 2011

---------, Sejarah Keberadaan Aksara Arab-Melayu di Nusantara dan Peranannya untuk Membaca Khazanah Intelektual Naskah-Naskah Melayu, Makalah disampaikan pada Seminar Internasional yang ditaja oleh Himpunan Mahasiswa Jurusan Pendidikan Bahasa Arab UIN Suska Riau Jumat 17 April 2015 di Islamic Center UIN Suska Riau, Makalah tidak diterbitkan.

Gilbert J. Garragha, A Guide to Historical Method, NewYork: Fordham University Press, 1963

Hamka, Antara Fakta dan Kenyataan Tuanku Rao, Jakarta: Bulan Bintang, 1974.

--------, Sejarah Umat Islam, Jilid II, Jakarta: Bulan Bintang, 1980

Hasbullah, "Dialektika Islam Dalam Budaya Lokal: Potret Budaya Melayu Riau," Jurnal Sosial Budaya, Vol. 11, No. 2. Juli-Desember 2014, ISSN: 1979-2603, Pekanbaru: LPPM UIN Suska Riau.

Helmiati, Dinamika Islam Asia Tenggara, Pekanbaru: Suska Press, 2008

Hussein Djajadiningrat, Kesultanan Aceh, Banda Aceh: Departeman P\&K, 1982 
Ellya Roza, Yasnel: Penetrasi Islam dalam Pendidikan Keagamaan...

Harimukti Kridalaksana, Masa Lampau Bahasa Indonesia: Sebuah Bunga Rampai, Yogyakarta: Sinar Harapan, 1991

Helius Sjamsuddin, Metodologi Sejarah, Terj. S. Aji, Yogyakarta: Ombak, 2007

H.A.R. Gibb, Shorter Encyclopedia of Islam, Leiden: E.J. Brill, 1974

Husni Thamrin, “Agama dalam Masyarakat Majemuk," Kutubkhanah Jurnal Penelitian Sosial Keagamaan, Vol. 10, No. 2, Juli-Desember 2007. ISSN:1693-8186. Pekanbaru: LPP UIN Suska Riau.

--------, “Agama, Politik dan Kekerasan” dalam Kutubkhanah Jurnal Penelitian Sosial Keagamaan.vol.10, no.1, Januari-Juni 2007, ISSN:1693-8186. Pekanbaru: LPP UIN Suska Riau.

dan Afrizal Nur, Pemetaan Kebudayaan Melayu Riau, Laporan Hasil Penelitian Universiti Islam Negeri Sultan Syarif Kasim Riau Pekanbaru, 2007

, Sejarah Hancurnya Singgasana Melayu I dan Timbulnya Singgasana Melayu II, Pekanbaru: Pemerintah Daerah Riau, 1984

Ira M. Lapidus, Sejarah Sosial Umat Islam, Terj. Ghufron A. Mas'adi, Jakarta: Raja Grafindo Persada, 2000

Imron Abu Umar, Sekitar Masalah Thariqat Naqsyabandiyah, Kudus: Menara, 1980

Jamaluddin Rabain, "Aktifitas Dakwah kepada Masyarakat Terasing Suku Talang Mamak," dalam Kutubkhanah Jurnal Penelitian Sosial Keagamaan, Vol. 8. No. 1, Juni 2006, ISSN:1693-8186, Pekanbaru: LPP UIN Suska Riau.

Jane Drakard (ed.), Sejarah Raja-raja Barus, Jakarta dan Bandung: Usaha Bersama Penerbit Angkasa dan Ecole Francaise D'ektreme-Orient, 1988

J. Vredenbergt, Metode dan Teknik Penelitian, Edisi ke-6 Jakarta: Gramedia.

Kuntowijoyo, Metodologi Sejarah, Yogyakarta: Tiara Wacana, 1994.

Kurnial Ilahi dan Khairiyah, "Peta Keagamaan Kabupaten Kuantan Singingi," Kutubkhanah Jurnal Penelitian Sosial Keagamaan, Vol. 10, No. 2, JuliDesember 2007, ISSN:1693-8186, Pekanbaru: LPP UIN Suska Riau.

Ladvik Kalus, "Sumber-sumber Epigraf Islam di Barus" dalam Claude Gulliot, Barus Seribu Tahun Yang Lalu, Terj. Daniel Perret \& Atika Sari Fanani, Jakarta, Paris: Pusat Penelitian dan Pengembangan Arkeologi Nasional, 2008

Louis Gottschalk, Mengerti Sejarah, Terj. Nugroho Notosusanto, Jakarta: UI Press, 1975

Mahidin Said, Adat dan Kebudayaan Pasir Pengaraian Riau, Pekanbaru: Badan Pembinaan Kesenian Daerah Riau, 2003

Mahyudin H. Yahya, Sejarah Islam, Kuala Lumpur: Fajar Bakti, 1993.

Martin Van Bruinessen, Tarekat Naqsyabandiyah di Indonesia, Bandung: Mizan, 1996

Mulyadhi Kartanegara, Menyelami Lubuk Tasawuf, Jakarta: Erlangga, 2006

Muhammad Dhiya Syahab dan Abdullah bin Nur, Al-Imam Al-Muhajir Ahmad bin Isa, Jeddah: Dar al-Syuruq, 1980

Mustafa Zahri, Kunci Memahami Ilmu Tasawuf, Surabaya: Bina Ilmu, 1979. 
Muchtar Lutfi, et.al. (eds.), Sejarah Riau, Pekanbaru: Biro Bina Setwilda Tingkat I Riau, 1999

M.D. Mansoer, et.al., Sejarah Minangkabau, Jakarta: Bharata, 1970.

Mahdini, Islam dan Kebudayaan Melayu, Pekanbaru: Daulat Riau, 2003

Nina Herlina, Metode Sejarah, Bandung: Satya Historika, 2008.

Nurfaisal, Kesaksian Barus dan Kapur Barus dalam Sejarah Awal Islam Nusantara, Laporan Hasil Penelitian yang tidak diterbitkan, Pekanbaru: LP2M UIN Suska Riau, 2013

Othman Soh, Sejarah Dunia SPM, Kuala Lumpur: Pustaka Delta, t.t.

Raja Ahmad dan Raja Ali Haji, Tuhfat al-Nafis, V, Matheson (ed.), Kuala Lumpur: Fajar Bakti

Rusli Amran, Sumatera Barat Hingga Plakat Panjang, Jakarta: Sinar Harapan, 1981.

Syed Naquib Al-Attas, Islam dalam Sejarah dan Kebudayaan Melayu, Kuala Lumpur: Universiti Kebangsaan Malaysia, 1972.

Syarif Alwi bin ThohirAl-Haddad, Al-Madkhal ila Tarikh al-Islami fi al-Syarq alAqsha, Jeddah: Alam al-Ma'rifah, 1985.

Shafie Abu Bakar, Kedatangan dan Perkembangan Ilmu Islam di Nusantara, Bangi: Penerbit UKM, t.th.

Siti Hawa Saleh, Hikayat Merong Mahawangsa, Kuala Lumpur: University Malaya Press, 1970

Suhayib, Pengaruh Pemikiran Tasawuf Said Nursi dalam Pemberdayaan Politik (AlTamkin al-Siyasi) di Turki (Studi atas Kitab Majmu'ah al-Maktubat), Disertasi yang tidak diterbitkan, Pekanbaru: PPS UIN Suska Riau, 2016

Suwardi Endaswara, Metode, Teori, Teknik Penelitian Kebudayaan, Yogyakarta: Pustaka Widyataman, 2006

Slamet Mulyana, Tafsir Sejarah Nagara Kretagamakarya Empu Prapanca, Yogyakarta: LKIS, 2006

Sartono Kartodirjo, Pemikiran dan Perkembangan Historiografi Indonesia Suatu Alternatif, Jakarta: Gramedia, 1982.

--------, Pendekatan Ilmu Sosial dalam Metodologi Sejarah, Jakarta: Gramedia, 1992

Taufik Abdullah, et.al. (eds.), Manusia dalam Kemelut Sejarah, Jakarta: LP3ES, Cet. ke-5

Tim Penyusun, Kamus Besar Bahasa Indonesia, Jakarta: Pusat Bahasa Indonesia, 2008.

Wan Hussein Azmi, "Islam di Aceh, Masuk dan Berkembangnya hingga Abad XVI," dalam A. Hasymi, Sejarah Masuk dan Berkembangnya Islam di Indonesia, Banda Aceh: Almaarif, 1993, Cet. ke-3

Wan Saleh Tamim, Lintasan Sejarah Rokan, Pekanbaru: BPKD Prop. Riau, 1972

Yusuf Abdullah Puar, Masuknya Islam ke Indonesia, Jakarta: CV. Indradjaja, 1984

Zuhairansyah dan Afrida, Pesantren dan Pendidikan: Mencari Jejak Jaringan Ulama Islam di Barus Kabupaten Tapanuli Tengah Propinsi Sumatera Utara, Hasil Penelitian tidak diterbitkan, Pekanbaru: LP2M UIN Suska Riau, 2015. 